\title{
Legal provision allied to conservation of heritage buildings in Penang
}

\begin{abstract}
Heritage culture and building in Penang have become among value asset in Malaysia. George Town inner cities most treasure architecture are located and can divided into several zone, it culture has been moulded by the succession of civilization that arrive and shaped its urban growth. Heritage building in the inner city exposes the sense of compromise between the pioneers, earlier settlers and later immigrants. The significant heritage character of George Town, Penang is reflect upon the predominant pre war buildings, the heritage buildings dates back to between late eighteen century and early nineteenth century. This paper will consider on Penang as World Heritage City, the conservation of the buildings in Penang and also legal provision related to conservation of heritage buildings in Penang.
\end{abstract}

Keyword: Georgetown; Heritage; Old building; Penang; Shop House; UNESCO 